\title{
50. GEOCHEMISTRY OF IGNEOUS ROCKS IN DEEP SEA DRILLING PROJECT HOLE 465A, HESS RISE: SIGNIFICANCE TO OCEANIC PLATEAU PETROLOGY AND EVOLUTION1,2
}

\author{
Robert B. Scott, ${ }^{3}$ Department of Geology, Texas A\&M University, College Station, Texas
}

\section{INTRODUCTION}

This is a report of a preliminary study of the geochemistry of volcanic rocks cored from acoustic basement at the base of Hole 465A, on Hess Rise, during Leg 62 of the Deep Sea Drilling Project. These new data will be integrated with knowledge of basementrock petrology and geochemistry from four other $\mathrm{Pa}$ cific oceanic plateaus, to construct a hypothetical model for the evolution of oceanic plateaus.

Figure 1 is a regional map showing these Pacific oceanic plateaus, and indicating DSDP holes or dredge sites. These plateaus (Shatsky, Hess, Magellan, OntongJava, and Manihiki) all have similar seismic characteristics, indicative of thick oceanic crust rather than continental crust (Den et al., 1969; Furumoto et al., 1976; Hussong et al., 1979; Winterer et al., 1973; Vallier, Thiede, et al., this volume). Hussong et al. (1979) demonstrated that these abnormal crustal thicknesses (2 to 5 times that of normal oceanic crust) can be viewed simply as a uniform amplification of the thickness of each oceanic seismic layer. If so, then the petrological process of creating an oceanic plateau may only be that of amplifying the rate of magma delivery to new crust.

Another significant similarity among these plateaus is the location of many at magnetic bights in the anomaly patterns, interpreted as the traces of ridge-ridge-ridge triple junctions (Hilde et al., 1977). Modern volcanic plateaus such as Iceland, the Azores, the Afar, or Galapagos may be analogous to these Pacific plateaus. This postulate will be tested by comparing the petrological, geological, and geochemical data from Hess Rise with those from other plateaus, both from Mesozoic Pacific and modern analogs.

The position of Site $465\left(33^{\circ} 49^{\prime} \mathrm{N}, 178^{\circ} 55^{\prime} \mathrm{E}\right)$ is indicated on a more detailed map of Hess Rise (Fig. 2). The site lies close to the junction of a northwesttrending arm and an east-west-trending arm of the rise. The chains of seamounts to the west and south of Hess Rise belong to the Emperor Seamount and Hawaiian Ridge chains, respectively. Six samples of volcanic rocks were made available from Hole $465 \mathrm{~A}$ by the Leg 62 shipboard party. The six samples are from six cores from the 24 meters of igneous rocks recovered from the acoustic basement of Hole 465A. The term acoustic basement may be somewhat misleading here, because

\footnotetext{
1 Initial Reports of the Deep Sea Drilling Project, Volume 62.

2 Texas A\&M University Geodynamics Research Project Contribution 0011.

${ }^{3}$ Present address: $223 \mathrm{~W}$. Maine, Marvel, Colorado 81623
}

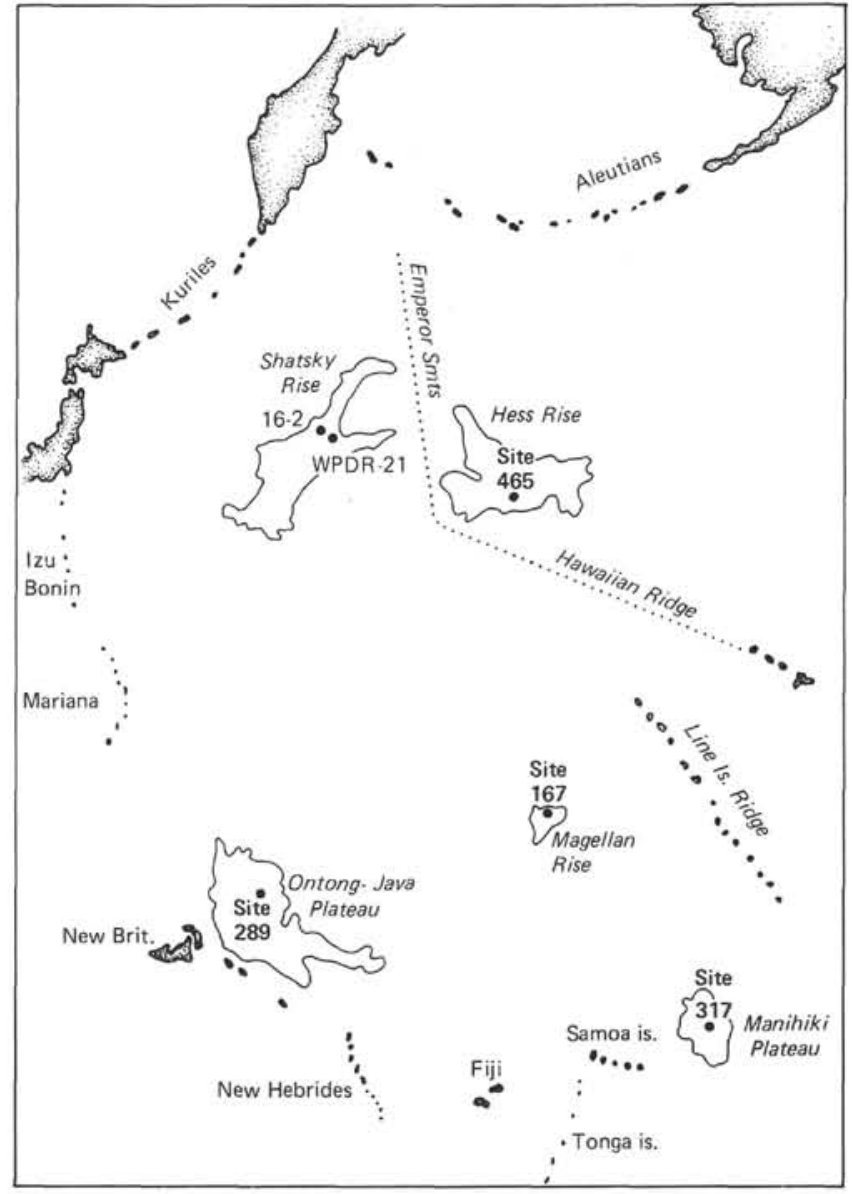

Figure 1. Location of five Pacific oceanic plateaus that have been sampled either by DSDP or by dredging. The drilling sites are indicated on the Ontong-Java Plateau, the Manihiki Plateau, the Magellan Rise, and Hess Rise. Two dredge positions are shown on Shatsky Rise, where basement was not reached.

the shipboard description (Site 465 report this volume) refers to a "pinnacle"'-shaped feature at acoustic basement. This is similar to the seismic character of a seamount decorating regional acoustic basement.

Petrographic descriptions by the Leg 62 shipboard scientific party emphasized that the recovered igneous rocks have no glassy margins and no indication of pillow structure, but do have abundant, large vesicles and red iron-oxide stains. These features are suggestive of subaerial exposure after eruption. In thin section, these volcanic rocks have a distinct trachytic texture of flowaligned plagioclase and potassium feldspar set in a 


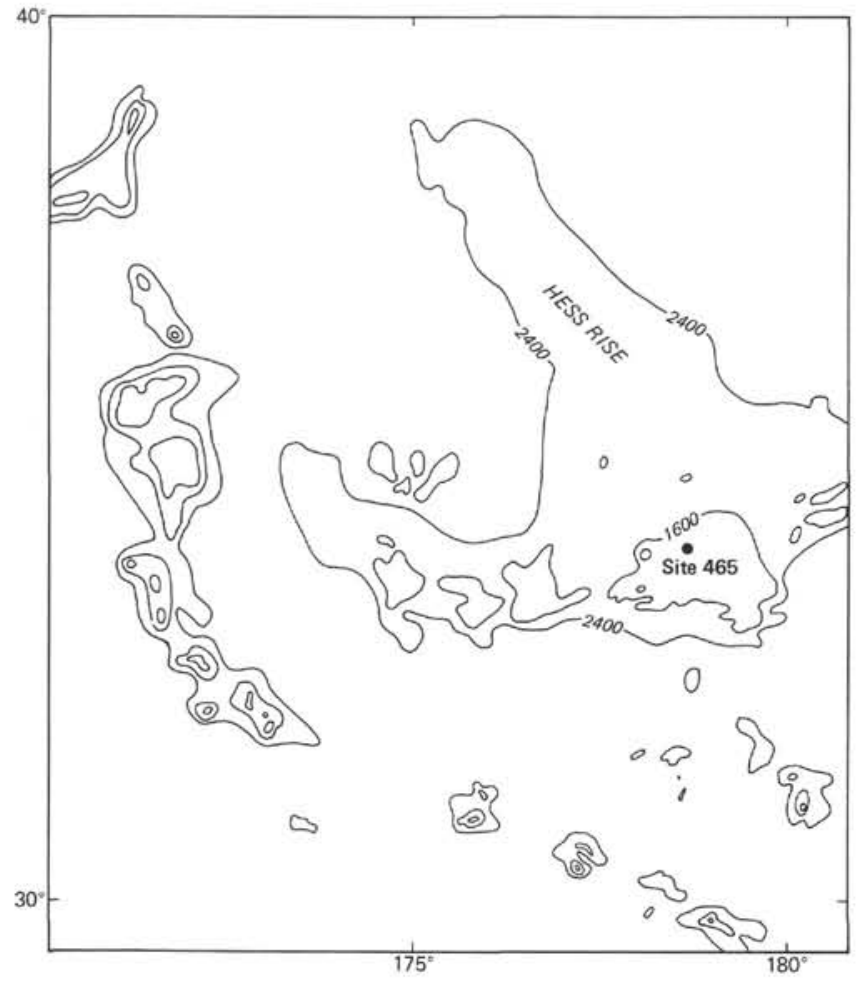

Figure 2. The location of Site 465 on Hess Rise (bathymetry in fathoms).

highly altered groundmass containing opaque minerals and clays. Smectites and possibly mixed-layer clays are indicated by X-ray diffraction, confirming the altered state of the groundmass.

\section{CHEMICAL METHODS AND RESULTS}

Portions of all six samples were crushed and powdered for whole rock major element analysis for $\mathrm{Al}, \mathrm{Fe}, \mathrm{Mn}, \mathrm{Mg}, \mathrm{Ca}, \mathrm{Na}$, and $\mathrm{K}$ by atomic absorption spectrophotometry (AAS) and $\mathrm{Si}$ and $\mathrm{Ti}$ by colorimetry using methods and having precision described in Scott and Hajash (1976). Powders from all these samples also were analyzed by instrumental neutron-activation analysis (INAA) for seven rare-earth elements, $\mathrm{La}, \mathrm{Ce}, \mathrm{Sm}, \mathrm{Eu}, \mathrm{Tb}, \mathrm{Yb}$, and $\mathrm{Lu}$ and for $\mathrm{Cr}, \mathrm{Co}, \mathrm{Fe}, \mathrm{Sc}$, and Hf; details of the methods and precisions are given in Tiezzi and Scott (1980). Five of these samples were analyzed by X-ray fluorescence (XRF) using techniques developed by Garrison (1979). Standards used for AAS and INAA were the U.S. Geological Survey standards BCR-1, GPS-1, and G-1; those for XRF were BCR-1, PCC-1, and AGV-1. Results for all these analyses are listed in Table 1.

\section{HESS RISE (HOLE 465A) CHEMISTRY}

Even though these rocks obviously have been altered by subaerial weathering, sea-water alteration, or some other process, the major-element abundances are similar to those of trachytes. Although analyses for $\mathrm{H}_{2} \mathrm{O}^{+}$, $\mathrm{H}_{2} \mathrm{O}^{-}$and $\mathrm{CO}_{2}$ were not made, it is assumed that the least-altered samples are those with the highest sums of major elements (those from Cores 44, 45, and 46). These samples also have the lowest $\mathrm{MgO}$ contents and highest $\mathrm{SiO}_{2}$ contents. The observed inverse $\mathrm{MgO} / \mathrm{SiO}_{2}$ relationship for these samples has a slope of approximately -1 , far greater than the typical trends for Atlantic alkalic oceanic islands (P. E. Baker, 1973). Thus, it is likely that the trend in Hole $465 \mathrm{~A}$ samples
Table 1. Hole 465A igneous geochemistry.

\begin{tabular}{|c|c|c|c|c|c|c|}
\hline $\begin{array}{c}\text { Core } \\
\text { Section } \\
\text { Interval }(\mathrm{cm}) \\
\text { Piece }\end{array}$ & $\begin{array}{c}41 \\
2 \\
19-20 \\
14\end{array}$ & $\begin{array}{c}42 \\
2 \\
58-60 \\
5\end{array}$ & $\begin{array}{c}43 \\
2 \\
25-26 \\
5 a\end{array}$ & $\begin{array}{c}44 \\
1 \\
116-117 \\
13 b\end{array}$ & $\begin{array}{c}45 \\
2 \\
12-13 \\
2\end{array}$ & $\begin{array}{c}46 \\
3 \\
55-56 \\
7\end{array}$ \\
\hline $\mathrm{SiO}_{2}$ (wt. \%) & 59.04 & 59.92 & 59.81 & 60.02 & 60.35 & 60.10 \\
\hline $\mathrm{TiO}_{2}$ & 0.97 & 0.95 & 0.99 & 0.97 & 1.02 & 1.00 \\
\hline $\mathrm{Al}_{2} \mathrm{O}_{3}$ & 18.5 & 18.8 & 19.3 & 19.9 & 19.3 & 18.8 \\
\hline $\mathrm{FeO}^{*}$ & $\begin{array}{c}2.91 \\
(3.01)\end{array}$ & $\begin{array}{c}2.49 \\
(2.61)\end{array}$ & $\begin{array}{c}2.34 \\
(2.44)\end{array}$ & $\begin{array}{c}2.70 \\
(2.82)\end{array}$ & $\begin{array}{c}2.58 \\
(2.73)\end{array}$ & $\begin{array}{c}2.19 \\
(2.31)\end{array}$ \\
\hline $\mathrm{MnO}$ & 0.015 & 0.011 & 0.023 & 0.033 & 0.034 & 0.032 \\
\hline $\mathrm{MgO}$ & 1.65 & 1.23 & 0.90 & 0.64 & 0.30 & 0.36 \\
\hline $\mathrm{CaO}$ & 2.40 & 2.17 & 2.45 & 2.36 & 2.22 & 2.27 \\
\hline $\mathrm{Na}_{2} \mathrm{O}$ & 5.25 & 4.92 & 5.98 & 5.84 & 5.35 & 5.25 \\
\hline $\mathrm{K}_{2} \mathrm{O}$ & 3.65 & 4.98 & 4.54 & 5.10 & 6.51 & 6.37 \\
\hline Total & 94.4 & 95.5 & 95.3 & 97.6 & 97.7 & 96.4 \\
\hline $\mathrm{Rb}(\mathrm{ppm})$ & - & 22.0 & 23.0 & 26.0 & 46.0 & 30.0 \\
\hline $\mathrm{Sr}$ & - & 250.0 & 350.0 & 300.0 & 250.0 & 280.0 \\
\hline $\mathrm{Zr}$ & - & 870.0 & 900.0 & 870.0 & 860.0 & 770.0 \\
\hline $\mathrm{Ni}$ & - & $<5.0$ & $<5.0$ & $<5.0$ & $<5.0$ & $<5.0$ \\
\hline $\mathrm{Cr}_{\mathrm{r}}$ & 12.6 & 5.8 & 5.5 & 4.6 & 6.4 & 6.9 \\
\hline Co & 4.9 & 4.3 & 3.3 & 2.9 & 3.6 & 3.5 \\
\hline La & 88.0 & 97.0 & 97.0 & 132.0 & 95.0 & 92.0 \\
\hline $\mathrm{Ce}$ & 171.0 & 186.0 & 183.0 & 177.0 & 182.0 & 176.0 \\
\hline $\mathrm{Sm}$ & 11.0 & 11.4 & 10.9 & 14.8 & 11.0 & 11.1 \\
\hline $\mathrm{Eu}$ & 3.29 & 3.22 & 3.33 & 3.16 & 3.26 & 3.31 \\
\hline $\mathrm{Tb}$ & 1.57 & 1.63 & 1.49 & 1.51 & 1.57 & 1.64 \\
\hline $\mathrm{Yb}$ & 1.68 & 1.94 & 1.93 & 1.77 & 1.68 & 1.68 \\
\hline Lu & 0.65 & 0.71 & 0.49 & 0.86 & 0.75 & 0.81 \\
\hline $\mathrm{Hf}$ & 18.1 & 17.2 & 14.9 & 15.0 & 18.0 & 15.7 \\
\hline $\mathrm{Sc}$ & 3.74 & 3.96 & 3.83 & 3.82 & 4.18 & 4.11 \\
\hline $\mathrm{K} / \mathrm{Rb}$ & - & 2300.0 & 2000.0 & 2000.0 & 1400.0 & 2100.0 \\
\hline $\mathrm{Rb} / \mathrm{Sr}$ & - & 0.088 & 0.066 & 0.087 & 0.18 & 0.11 \\
\hline
\end{tabular}

-Total $\mathrm{Fe}$ as $\mathrm{FeO},(\mathrm{FeO})=$ determined by INAA; - not determined.

does not reflect magmatic differentiation, but alteration. It should be noted that strontium-isotope-ratio differences between rocks representing different stages of magmatic differentiation in these Atlantic volcanic suites preclude the possibility of single-stage crystal fractionation as the differentiation process; P. E. Baker (1973) therefore suggested that the more-evolved lavas of these suites were derived from remelting of older silicic rocks fractionated in an earlier stage from basaltic magmas. Such possibilities should be investigated by isotopic studies of Hess Rise rocks.

A comparison of the chemistries of the least-altered samples from Hess Rise with chemistries of oceanic islands shows that the major elements of trachytes and related mildly alkalic rocks (P. E. Baker, 1973) from Tristan da Cunha, Gough, Fernando de Noronha, Hawaii, and St. Helena (Table 2), are similar to those of rocks from Hess Rise. The trachyte from St. Helena is consistently more sodic; the phonolite from St. Helena and the Hawaiian trachyte are both more sodic and much more evolved or differentiated; the trachyandesite of Gough is considerably more primitive; and the alkalic trachyte from Fernando de Noronha is very similar to Hole $465 \mathrm{~A}$ rocks, except for higher $\mathrm{SiO}_{2}$ and $\mathrm{Na}_{2} \mathrm{O}$ values. But by far the most similar analyses are of the trachytes from Tristan da Cunha, and the average of the two is even closer to Hess Rise analyses. Even these rocks are somewhat sodium-rich to be close analogs of the Hess Rise trachytes; these mildly alkalic lavas of the Hess Rise have higher $\mathrm{K} / \mathrm{Na}$ ratios than do Atlantic suites.

Clearly the chondrite-normalized REE patterns of Hole 465A samples have distinctive light (L) REE 
Table 2. Comparison of major-element chemistry of trachytic rocks from oceanic islands with Hole 465A rocks from Hess Rise.

\begin{tabular}{|c|c|c|c|c|c|c|c|c|c|}
\hline & $\begin{array}{l}\text { Average } \\
\text { Trachyte, } \\
\text { Hole 465A, } \\
\text { Hess Rise }\end{array}$ & $\begin{array}{c}\text { Trachyte } \\
31, \\
\text { Tristan } \\
\text { da Cunha }\end{array}$ & $\begin{array}{c}\text { Trachyte } \\
560, \\
\text { Tristan } \\
\text { da Cunha }\end{array}$ & $\begin{array}{c}\text { Average } \\
\text { Trachyte, } \\
\text { Tristan } \\
\text { da Cunha }\end{array}$ & $\begin{array}{c}\text { Trachyte } \\
763, \\
\text { St. } \\
\text { Helena }\end{array}$ & $\begin{array}{c}\text { Phonolite } \\
\text { 11, } \\
\text { St. } \\
\text { Helena }\end{array}$ & $\begin{array}{c}\text { Trachyandesite } \\
\text { G22, } \\
\text { Gough }\end{array}$ & $\begin{array}{c}\text { Alkalic Trachyte } \\
10, \\
\text { Fernando de } \\
\text { Noronha }\end{array}$ & $\begin{array}{c}\text { Trachyte } \\
8, \\
\text { Hualalai } \\
\text { Hawaii }\end{array}$ \\
\hline $\mathrm{SiO}_{2}$ & 61.9 & 61.5 & 58.8 & 60.2 & 60.8 & 61.0 & 56.2 & 62.3 & 63.2 \\
\hline $\mathrm{TiO}_{2}$ & 1.03 & 0.5 & 1.2 & 0.8 & 0.43 & 0.06 & 1.73 & 0.67 & 0.32 \\
\hline $\mathrm{Al}_{2} \mathrm{O}_{3}$ & 19.8 & 20.8 & 19.7 & 20.0 & 18.0 & 20.2 & 18.0 & 19.5 & 19.1 \\
\hline $\mathrm{FeO}^{*}$ & 2.56 & 2.5 & 3.8 & 3.1 & 6.02 & 3.26 & 7.13 & 2.39 & 4.05 \\
\hline $\mathrm{MnO}$ & 0.03 & 0.20 & 0.1 & 0.15 & 0.22 & 0.18 & 0.12 & tr. & n.d. \\
\hline $\mathrm{MgO}$ & 0.44 & 0.20 & 1.0 & 0.6 & 0.51 & 0.05 & 2.27 & 0.63 & 0.41 \\
\hline $\mathrm{CaO}$ & 2.35 & 1.40 & 3.3 & 2.4 & 2.31 & 1.09 & 4.51 & 1.75 & 0.88 \\
\hline $\mathrm{Na}_{2} \mathrm{O}$ & 5.64 & 6.3 & 6.6 & 6.5 & 7.70 & 9.10 & 5.11 & 6.39 & 7.03 \\
\hline $\mathrm{K}_{2} \mathrm{O}$ & 6.16 & 6.8 & 5.4 & 6.1 & 4.10 & 5.02 & 4.85 & 5.98 & 5.02 \\
\hline
\end{tabular}

Note: All values are in weight percent. $\mathrm{FeO}^{*}$ is total $\mathrm{Fe}$ expressed as $\mathrm{FeO}$; n.d. = not determined; tr. = trace; all values are recalculated to a sum of $100 \%$. Tristan da Cunha analyses from P. E. Baker et al. (1964); Gough analyses from Le Maitre (1962); St. Helena analyses from I. Baker (1962); Fernando de Noronha analysis from Almeida (1955); Hawaii analysis from Macdonald (1949). Hess Rise Hole $456 \mathrm{~A}$ values are averages for three samples from Cores 44,45 , and 46 (Table 1).

enrichment and are characteristic of alkalic rocks (Fig. 3). The samples have very little variation between REE patterns, except Sample 465A-44-1, 116-117 cm, which has slightly higher $\mathrm{La}$ and $\mathrm{Sm}$ values. There is an increase in the scatter of $\mathrm{La}$ over that of $\mathrm{Ce}$ and $\mathrm{Sm}$; this may be the effect of La alteration by reaction with sea water, or the effect of an orthomagmatic process on LREE, although no correlation with major-element variations is apparent. There is also an apparent progressive increase in the scatter in the heavy $(\mathrm{H}) \mathrm{REE}$ where $\mathrm{Lu}$ varies between 0.59 and $0.86 \mathrm{ppm}$. The percent variation changes from $45 \%$ for $\mathrm{Lu}$, to $15 \%$ for $\mathrm{Yb}$, to $10 \%$ for Eu, to less than $5 \%$ for Sm. Such a trend suggests that a magmatic process affected small REE to a greater degree than large REE during differentiation of these alkalic magmas. An unambiguous explanation of this observation will have to await more discriminating research.

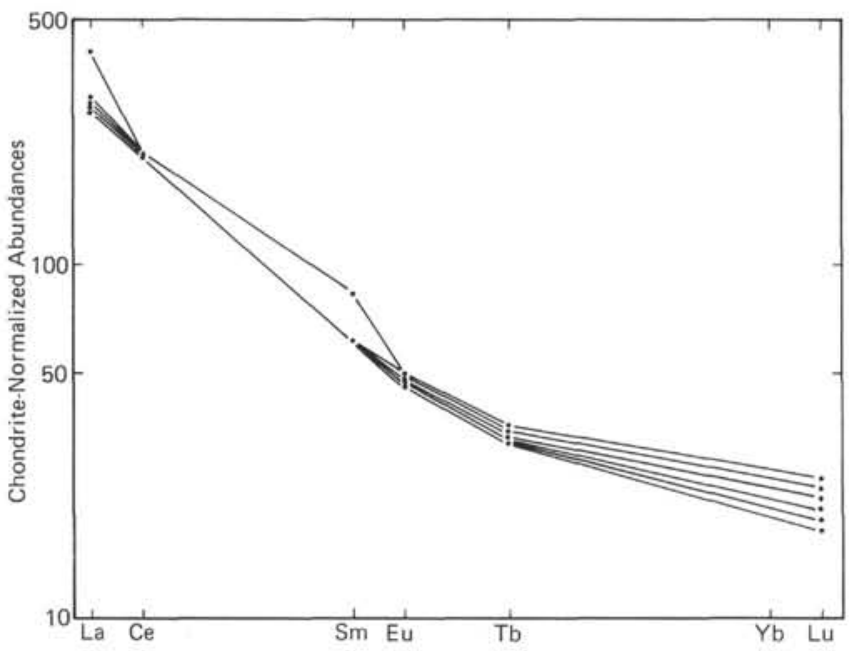

Figure 3. Chondrite-normalized REE abundance (sample REE/chondrite REE) versus atomic number from $\mathrm{La}(57)$ to $\mathrm{Lu}(71)$ for the six samples from Hole 465A. The average chondrite REE abundance was used for normalization (Herrmann, 1970).
Although LREE enrichment is also characteristic of trachytic rocks from the islands of Gough, Ascension, and Hawaii (Frey et al., 1968; Schilling and Winchester, 1969), the departures from the Hess Rise patterns are significant (Fig. 4). The Gough trachyte has a considerably higher REE abundance for both LREE and HREE than Hole 465A rocks, and a large negative Eu anomaly dominates the Gough pattern, whereas none exists with the Heśs Rise trachytes. The trachyandesite of Gough is not as enriched in LREE, has higher intermediate REE and lower HREE than do the Hess Rise trachytes. The REE pattern of the Hawaiian trachyte is similar to that of Hole 465A rocks, but has consistently less-abundant LREE. Even though the LREE abun-

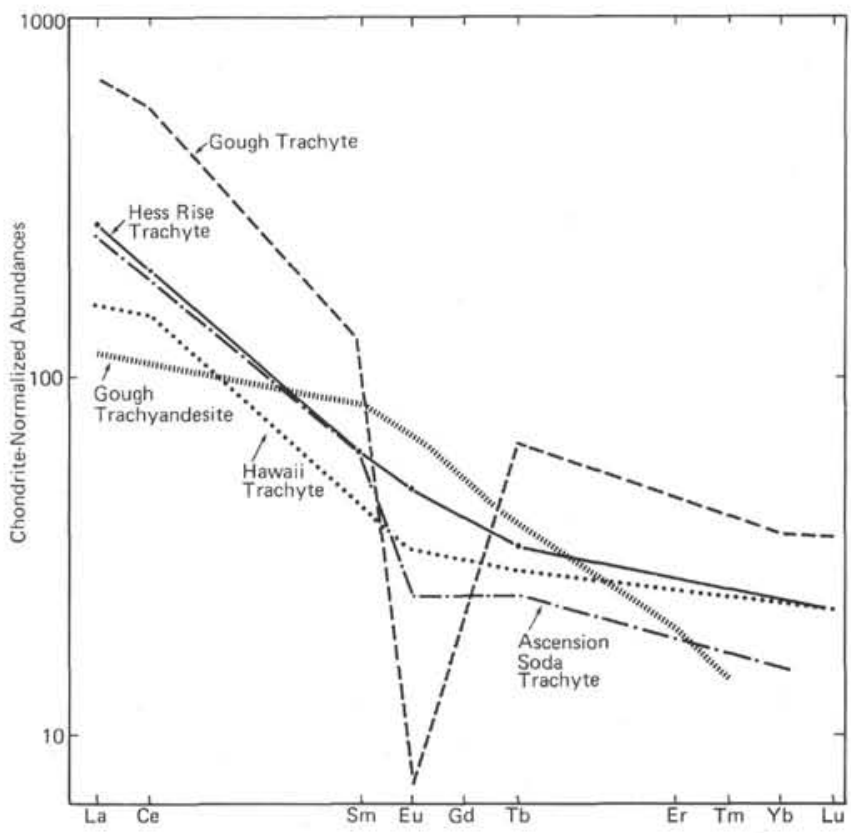

Figure 4. Comparison of the REE patterns of trachytic rocks from the island of Gough, Hawaii, and Ascension with the average for those on Hess Rise, Hole 465A. 
dance in the Ascension soda trachyte is very similar to that of Hess Rise trachytes, the negative Eu anomaly and lower HREE abundance make it distinct.

It is obvious that these alkalic suites have undergone variable undetermined petrological processes that have resulted in decoupling of major elements from trace elements. This is easily demonstrated by observations of large negative Eu anomalies in some rock suites, probably the result of plagioclase fractionation, and, in contrast, other rock suites with very similar major-element chemistries, but without appreciable Eu anomalies. Apparently, generation of the Hess Rise trachytic magma did not involve plagioclase fractionation.

\section{COMPARISON WITH OTHER PACIFIC PLATEAUS}

Descriptions of the southern three plateaus (Fig. 1) indicate a shallow-water or subaerial origin, judging from the abundant vesicles and the absence of pillow lavas and chilled glassy borders, which are usually found in submarine extrusive rocks (Bass et al., 1973; Stoeser, 1975; Jackson et al., 1976) - all very similar to features discussed earlier for the Hess Rise. All these Mesozoic plateaus (Hess, Ontong-Java, Magellan, and Manihiki) are old enough to have reached abyssal depths if they followed a normal mid-ocean-ridge crustal evolution, originating from normal mid-oceanridge depths (Sclater et al., 1971) and submerging approximately $3.5 \mathrm{~km}$ during that process. Their present higher elevations appear to require a different evolution. However, if they were originally formed at shallow depths or even with slight subaerial relief, and if the isostatic effect of the unusual thicknesses of biogenic sediments is compensated, then these plateaus have also submerged roughly $3.5 \mathrm{~km}$. Thus, it is concluded that the processes that control submergence of the plateaus probably are similar to those that control normal oceanbasin bathymetry and are consistent with present plateau depths.

Geochemical studies of the three southern Pacific plateaus seem to indicate major petrological differences between Hess Rise and these southern plateaus. For example, from a trace-element study, Bass et al. (1973) consider the Magellan Rise basement at Site 167 to be either an altered tholeiitic mid-ocean-ridge basalt (MORB) or a basalt transitional with ocean-island tholeiite. Jackson et al. (1976) found the basement of Manihiki Plateau at Site 317 to have MORB traceelement characteristics; Stoeser (1975) reached the same conclusion for the basement of Ontong-Java at Site 298. Comparisons between some of the incompatible, large, highly-charged ions confirm these conclusions. For example, a plot of $\mathrm{Zr}$ versus $\mathrm{Sr}$ (Fig. 5) indicates that Hess Rise trachytes fall far from the basalt fields, as expected. However, differences between Hess Rise and the southern plateaus may not be as great as these data seem to indicate; in a more-complete petrological study of igneous rocks recovered from Hess Rise on Leg 62 , Seifert et al. (this volume) report oceanic tholeiites from Site 464 , and also confirm Site 465 observations.

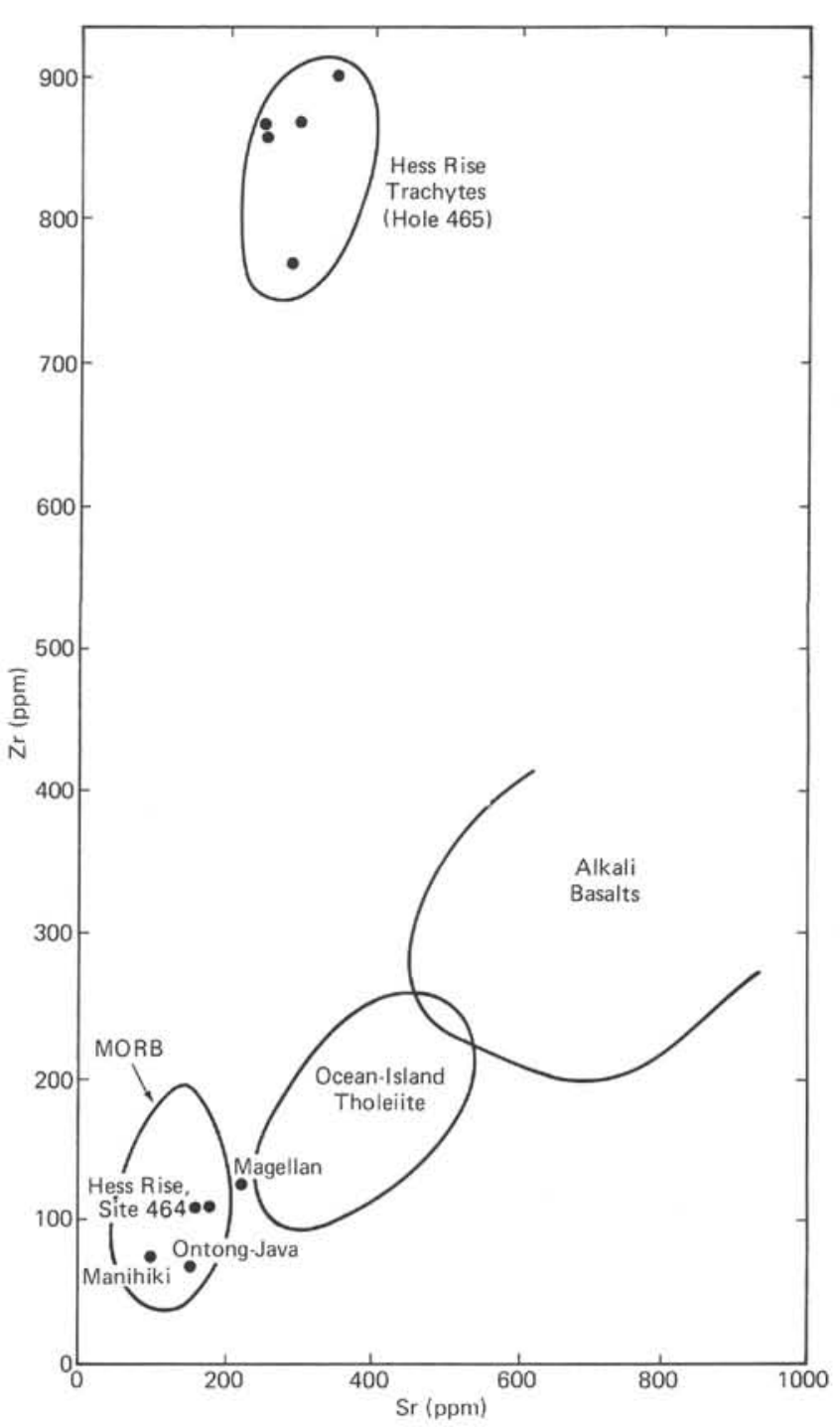

Figure 5. Plot of $\mathrm{Zr}$ versus $\mathrm{Sr}$ values for fields of MORB, oceanicisland tholeiite, and alkali basalt (after Bass et al., 1973). The Hess Rise data are plotted for comparison with data from Manihiki and Ontong-Java Plateaus and Magellan Rise.

Data for Hole 464 are also plotted in Figure 5 and clearly meet the $\mathrm{Zr}$ and $\mathrm{Sr}$ criteria for MORB.

Very limited REE data are available for oceanic plateaus. The summary of available REE patterns plotted in Figure 6 includes the Hole 465A trachytic average from this study, the Hole 464 tholeiitic average (Seifert et al., this volume), an average of three analyses from Shatsky Rise (Scott, unpublished data), and tholeiitic basement from Manihiki (Jackson et al., 1976). Clearly the rocks dredged from seamounts on Shatsky Rise (Sites 16-2 and WPDR-21; Ozima et al., 1970, 1971) are very similar to the Hess Rise trachytes, but unfortunately are too altered for comparison of major-element data. The Leg 62 shipboard description of the "pinnacle"-like feature from which the Hess Rise trachytes were recovered, the REE similarities to Shatsky seamounts, and the similarities to oceanic-island major- 


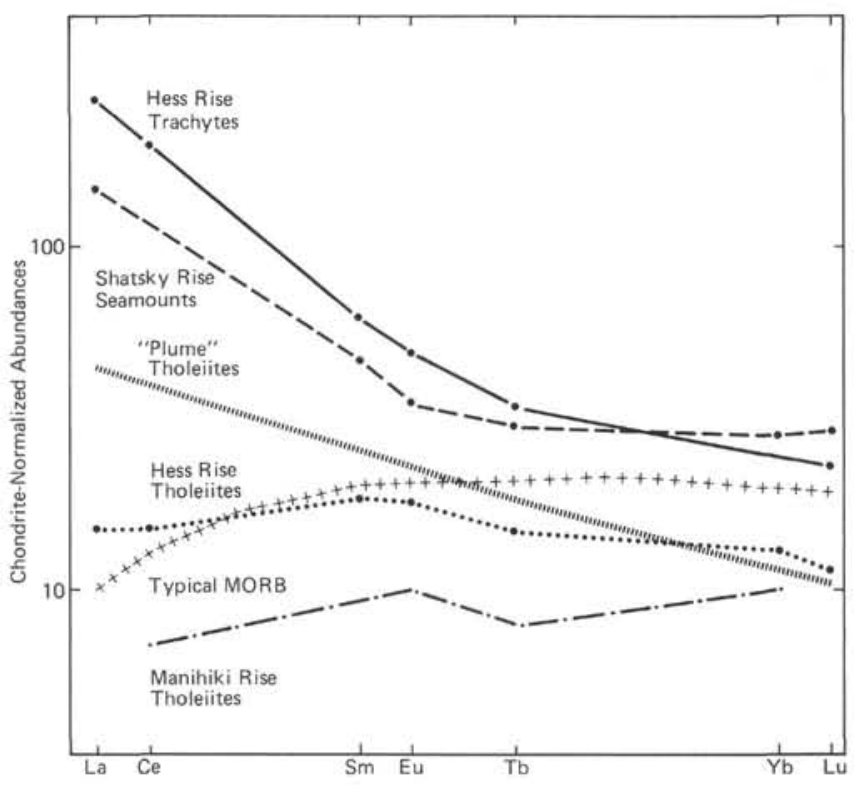

Figure 6. Chondrite-normalized abundance of REE in rocks from Hess, Shatsky, and Manihiki rises, plotted against atomic position on periodic table.

element chemistry discussed earlier all make it seem logical to assume that this pinnacle on Hess Rise is also a seamount decoration on lower crust.

It is also clear that Hess Rise tholeiites (Hole 464; Seifert et al., this volume) are somewhat similar to typical MORB (Kay et al., 1970), judging from REE patterns. However, the pronounced decrease in HREE and the lack of depletion of LREE makes the Hess Rise tholeiites slightly distinct. The low HREE abundance may reflect the presence of garnet in the mantle source of Hess Rise tholeiites. Although Manihiki Rise tholeiites have an unusually low abundance of REE, the same general Hess Rise-type patterns exist. These tholeiites and those from Magellan and Ontong-Java Plateaus seem to be acoustic basement. Thus, from these lines of evidence, it appears likely that ocean plateaus, like much of the normal ocean crust, have had their tholeiitic crust decorated with alkalic volcanoes, the major difference being that plateau volcanoes probably have had a subaerial history, at least for a short period before submergence.

The principal true distinction between normal midocean crust and that of plateaus seems to be that petrogenetic processes built elevated regions with amplified crustal thickness at plateau sites. The aforementioned association of these Pacific plateaus with ridge-ridgeridge triple junctions at the time of origin (Hilde et al., 1977), now indicated by their position on magnetic bights, suggests a "plume"-type origin; certainly the overall size and morphology of so-called plumes such as Iceland, the Azores, and the Galapagos are not significantly different from those of oceanic plateaus. However, comparison of the REE patterns of the plumes (Schilling, 1973, 1975) and those of Hess and Manihiki
Rise tholeiites indicates that plumes are characterized by significantly greater LREE enrichment. In fact, Hess Rise tholeiite patterns seem to fall between those of plumes and MORB REE patterns. Obviously, the magmatic processes of plateau formation are an important factor of ocean-crust formation; yet only a few samples of basement from only four plateaus are available for study. A systematic study of these samples has yet to be done; very little isotopic data exist.

All these factors make it obvious that a thorough study of plateau origin is very much in need. Such need for further study is also emphasized by the suggestion that the Permo-Triassic displaced blocks of Wrangellia, which compose significant parts of northwestern North America, have many features in common with oceanic plateaus (Jones et al., 1977).

\section{CONCLUSIONS}

Study of the geologic, bathymetric, petrographic, petrologic and geochemical character of Hess Rise trachytes of Hole 465A (in conjunction with other studies of those features in Hess Rise tholeiites, Hole 464; Seifert et al., this volume), tholeiites from Magellan Rise and Ontong-Java and Mankhiki Plateaus, and seamounts from Shatsky Rise has led to several conclusions:

1) The chemistry of the Hess Rise trachytes of Hole $465 \mathrm{~A}$ is essentially that of a mildly alkalic, somewhat potassic, seamount.

2) The Hess Rise trachytes were probably recovered from a seamount that is part of seamount decoration of the type very commonly associated with plateau morphology.

3) Below such decoration on oceanic plateaus, a tholeiitic basement exists.

4) At the time of formation, oceanic plateaus were subaerially exposed, or nearly so.

5) Although magnetic-anomaly patterns suggest a “plume"'-type origin, very limited REE evidence suggests that these plateaus are distinctly different in chemistry from both "plumes" and normal MORB.

6) The major distinction between the petrologic processes that create oceanic plateaus and those that create normal ocean crust is the simple amplification of magma generation, resulting in abnormally thick oceanic crust (Scott, 1979).

\section{ACKNOWLEDGMENTS}

I appreciate the reviews of this manuscript by Andrew Hajash and Thomas Tieh. Research was supported in part by NSF grant OCE 78197700 .

\section{REFERENCES}

Almeida, F. F. M. de, 1955. Geologia e petrologia do Arquipelago de Fernando de Noronha: Rio de Janeiro. Depto. Nac. Producao Min. Div. Geol. Mineral. Monogr., 13.

Baker, I., 1962. Petrology of the volcanic rocks of Saint Helena Island, South Atlantic. Geol. Soc. Am. Bull., 73:1309-1340.

Baker, P. E., 1973. Islands of the South Atlantic. In Nairn, A. E. M., and Stehli, F. G. (Eds.), The Ocean Basin and Margins: New' York (Plenum), pp. 493-553. 
Baker, P. E., Goss, I. G., Harris, P. G., et al., 1964. The volcanological report of the Royal Society expedition to Tristan da Cunha 1962. Phil. Trans. Royal Soc. London, A256:439-578.

Bass, M. N., Moberly, R., Rhodes, J. M., et al., 1973. Volcanic rocks cored in the Central Pacific, Leg 17, Deep Sea Drilling Project. In Winterer, E. L., Ewing, J. I., et al., Init. Repts. DSDP, 17: Washington (U.S. Govt. Printing Office), 429-466.

Den, N., Ludwig, W. J., Murauchi, S., et al., 1969. Seismic refraction measurements in the northwest Pacific Basin. J. Geophys. Res., $74: 1421-1434$

Frey, F. A., Haskin, M. A., Poetz, J. A., et al., 1968. Rare earth abundances in some basic rocks. J. Geophys. Res., 73:6085-6089.

Furumoto, A. S., Webb, J. P., Odegard, M. E., et al., 1976. Seismic studies on Ontong-Java Plateau, 1970. Tectonophysics, 34:71-90.

Garrison, J. R., 1979. Petrology and geochemistry of the Precambrian Coal Creek serpentinite mass and associated metamorphosed basaltic and intermediate rocks, Llano Uplift, Texas [Ph.D. dissert.]. Univ. of Texas, Austin.

Herrmann, A. G., 1970. Yttrium and lanthanides: abundance in cosmos, meteorites, tectites and lunar samples. In Wedepohl, K. H., (Ed.), Handbook of Geochemistry: New York (SpringerVerlag), 57-71, C1-C10.

Hilde, T. W. C., Uyeda, S., and Kroenke, L., 1977. Evolution of the Western Pacific and its margin. Tectonophysics, 38:145-165.

Hussong, D. M., Wipperman, L. K., and Kroenke, L. W., 1979. The crustal structure of Ontong-Java and Manihiki ocean plateaus. $J$. Geophys. Res., 84:6003-6010.

Jackson, E. D., Bargar, K. E., Fabbi, B. P., et al., 1976. Petrology of basaltic rocks drilled on Leg 33 of the Deep Sea Drilling Project. In Schlanger, S. O., Jackson, E. D., et al., Init. Repts. DSDP, 33: Washington (U.S. Govt. Printing Office), 915-927.
Jones, D. L., Silberling, N. J., and Hillhouse, J., 1977. Wrangellia-a displaced terrane in northwestern North America. Can. J. Earth Sci., 14:2564-2678.

Kay, R., Hubbard, N. J., and Gast, P. W., 1970. Chemical characteristics and origin of ocean ridge volcanic rocks. J. Geophys. Res., 75:1585-1613.

Le Maitre, R. W., 1962. Petrology of volcanic rocks, Gough Island, South Atlantic. Geol. Soc. Am. Bull., 73:1309-1340.

Macdonald, G. A., 1979. Petrography of the Island of Hawaii. U.S. Geol. Survey Prof. Paper, 214-D:51-96.

Ozima, M., Kaneoka, I., and Aramaki, S., 1970. K-Ar age of submarine basalts dredged from sea mounts in the Western Pacific and discussion of oceanic crust. Earth Planet. Sci. Lett., 8: 237-249.

Ozima, M., Zashu, S., and Veno, N., 1971. K/Rb and ${ }^{87} \mathrm{Sr} /{ }^{86} \mathrm{Sr}$ ratios of dredged submarine basalts. Earth Planet. Sci. Lett., 10:239444.

Schilling, J-G., 1973. Iceland mantle plume: geochemical study of Reykjanes Ridge. Nature, 242:565-567.

1975. Azores mantle blob: rare-earth evidence. Earth Planet. Sci. Lett., 25:103-115.

Schilling, J-G., and Winchester, J. W., 1969. Rare-earth contribution to the origin of Hawaiian lavas. Contr. Mineral. Petrol., 23:27-37.

Scott, R. B., 1979. Petrology and geochemistry of ocean plateaus: implications for their origin. Trans. Am. Geophys. Union., 60:949.

Stoeser, D. B., 1975. Igneous rocks from Leg 30 of the Deep Sea Drilling Project. In Andrews, J. E., Packham, G., et al., Init. Repts. DSDP, 30: Washington (U.S. Govt. Printing Office), 401-444.

Winterer, E. L., Ewing, J. I., et al., 1973. Part I: site reports. In Winterer, E. L., Ewing, J. I., et al., Init. Repts. DSDP, 17: Washington (U.S. Govt. Printing Office), 3-334. 